\title{
THE PROPERTIES OF PARTICLES PRODUCED FROM WASTE PLYWOOD BY SHREDDING IN A SINGLE-SHAFT SHREDDER
}

\author{
Agnieszka Laskowska ${ }^{1, \star}$, Mariusz Mamiński ${ }^{1}$
}

\begin{abstract}
The present work regards an attempt to obtain particles from the post-industrial pine plywood in a single-shaft shredder. A screen mesh size determines the wood particles characteristics. In the work 10-, 14-, 25and 38-mm mesh size screens were used. The urea-formaldehyde (UF) and phenol-formaldehyde (PF) bonded plywood were shredded separately, so that the effect of the binder type could be analyzed. The determined fractional composition, bulk density, dimensions and surface area of the particles were compared to the industrial virgin pine particles dedicated to the core layer of particleboards. The results showed that the particles obtained from a 14-mm mesh screen exhibited properties closest to those found for the virgin particles.
\end{abstract} resin.

Keywords: Bulk density, particleboard, plywood, post-industrial waste wood, recycled wooden wastes,

\section{INTRODUCTION}

Due to the limited forest resources and constantly developing economy, the wood industry in Europe has been experiencing wood deficiency for a few years. Particleboard and fiberboard sectors have been especially affected (Mantau 2010). An increasing utilization of biomass as a biofuel in the energy sector promoted by financial support from EU is a serious risk of limiting the wood supply for wood-based panels industry, in particular for particleboard and fiberboard producers. It was estimated that wood deficiency would reach 200 million $\mathrm{m}^{3}$ and 300 million $\mathrm{m}^{3}$ in 2025 and 2030, respectively (Zbořil and Pesci 2011). A possible way to reduce the deficiency is reuse of post-industrial and recycled wooden wastes (Lykidis and Grigoriou 2008, Kurowska 2015, Azambuja et al. 2018). In the future a more complex recycling system will be developed to allow isolate wood grades that are useless in particleboard industry, thus thermal conversion seems rational way for their exploitation. Moreover, such approach is fully justified in the light of the EU regulations on the promotion of the use of energy from renewable sources (European Parliament, Council of the European Union 2009).

The use of waste wood or waste panels is a potential resource in raw material supply. The wastes containing small amounts of synthetic amino or phenolic resins adhesives, hydrophobic agents or coatings are still not completely exploited (Hillring et al. 2007, Merl et al. 2007, Van Benthem et al. 2007). These are wastes from panel edging, used furniture, demolition wood, window frames and wood-based panels e.g. OSB, glulam and plywood (Kurowska 2016).

In the literature, there are few reports on the utilization of wood scraps containing synthetic binders in particleboard production (Czarnecki et al. 2003, Demirkir and Çolakoğlu 2007, Lykidis and Grigoriou 2008). Unfortunately, the reports lack data on the conditions of particle shredding and their geometry. A complex analysis of the particles is justified since their properties determine the properties of the particleboards (Nemli et al. 2007, Nazerian et al. 2011, Azambuja et al. 2018, Bardak et al. 2019). The particles properties depend on the material characteristics and the conditions of shredding process (Hernández et al. 2014).

Particles are characterized by fractional composition, dimensions, distribution of thickness around means, shape factors, bulk density, surface area (Suchsland and Woodson 1991, Gamage et al. 2009, Nazerian et al. 2011). It was stated that short and thick particles reduce bending strength and modulus of elasticity (Mundy 
and Bonfield 1998). Bulk density depends on the shape and dimensions of particles. Fine particles and dust are more tightly packed in a volume unit. Thus, the higher content of fine fractions and dust in the mixture, the greater specific surface area, and lower bondline area are. In consequence, physical and mechanical properties of particleboards are reduced (Nemli et al. 2007, Sackey et al. 2008). Moisture content is another parameter to affect particleboard pressing. Heat transfer to the core of a mat depends on the moisture content and is intensified for higher moisture levels.

High content of particles of high bulk density renders less compact mats, easier to penetrate for the steam, and, subsequently, time necessary to achieve target temperature in the core is shorter (Graser 1962, Humphrey and Bolton 1989, Bolton et al. 1989, Thoemen and Humphrey 2001). On the other hand, too high moisture content may result in delamination in panels.

In the present work a single-shaft shredder was used to produce particles from post-industrial plywood. This type of the machine is commonly used in industry for shredding wastes from the round wood and lumber processing. Thus, it was chosen as an alternative to the specialized equipment dedicated to disintegration of wood-based composites. The objective of the investigations was to shred waste plywood to particles in a one-step operation and to define the process parameters allowing to produce particles that exhibit properties comparable to those of the industrial virgin particles for the core layer of particleboard. The effect of the binder on the fractional composition, bulk density, dimensions and surface area of the particles was analyzed.

\section{MATERIAL AND METHODS}

The raw UF- and PF-bonded pine (Pinus sylvestris L.) plywood (500 kg each) was obtained from two plants where the waste was generated from the edging operations. Panels of 7, 12, 16, $22 \mathrm{~mm}$ thickness; density $660 \mathrm{~kg} / \mathrm{m}^{3}$; moisture content $6 \%$ were composed of the 1,$4 ; 1,8 ; 2,2$ or $2,5 \mathrm{~mm}$ thick veneers. Binder load was $160 \mathrm{~g} / \mathrm{m}^{2}$. Total amount of binder was $75 \mathrm{~kg}$ per $1 \mathrm{~m}^{3}$ of plywood - i.e. $\mathrm{ca} .14 \%$ by weight.

Shredding was performed in a single-shaft shredder equipped with 10-, 14-, 25- and 38-mm mesh screens and 2,21 mm knife-counter knife gap. Industrial virgin pine particles (P_CL) dedicated to core-layer of particleboard were used as the reference.

The present work contains a comparison of the properties of particles recovered from waste plywood and industrial virgin particles. Fractional composition, bulk density, thickness, distribution of thickness around means, width, length and surface area were determined. Moisture content was determined gravimetrically with $0,1 \%$ accuracy. Particle fractions were determined using a laboratory sorter equipped with 10,$00 ; 8,00 ; 6,00$; 4,$00 ; 2,00 ; 1,25 ; 0,63 ; 0,32 \mathrm{~mm}$ mesh sieves. Twelve 100-gram portions were sorted for each batch. Particle bulk density was determined as follows: particles were poured into a $0,002 \mathrm{~m}^{3}$ vessel $(100 \mathrm{~mm}$ diameter, 260 $\mathrm{mm}$ height) and weighted. The value was referred to $1 \mathrm{~m}^{3}$ volume.

Length and width were analyzed with $0,1 \mathrm{~mm}$ accuracy using a microscopic method. Thickness was measured with a micrometer with $0,01 \mathrm{~mm}$ accuracy. Forty particles in each fraction were measured. The average dimensions were determined from the weighted average in individual fractions. The surface area was computed according to the relations reported by Meyer (1969). For the calculations of surface area of industrial virgin pine (Pinus sylvestris L.) particles density was $460 \mathrm{~kg} / \mathrm{m}^{3}$ (determined for dry wood according to ISO 13061-2 (2014)). Surface area of the recovered particles was calculated for the density $638 \mathrm{~kg} / \mathrm{m}^{3}$ determined as described in EN 323 (1993). Statistical analysis was performed using STATISTICA Version-12 software of StatSoft, Inc. (Tulsa, USA). Dunnett's test was used for the statistical analysis with significance level 0,05.

\section{RESULTS AND DISCUSSION}

Six grades of the recovered particles were obtained: 10_UF, 10_PF, 14_UF, 14_PF, 25_PF, 38 PF, where: the number denotes screen mesh size, UF or PF denotes the adhesive type (Figure $\overline{1}$ ). 


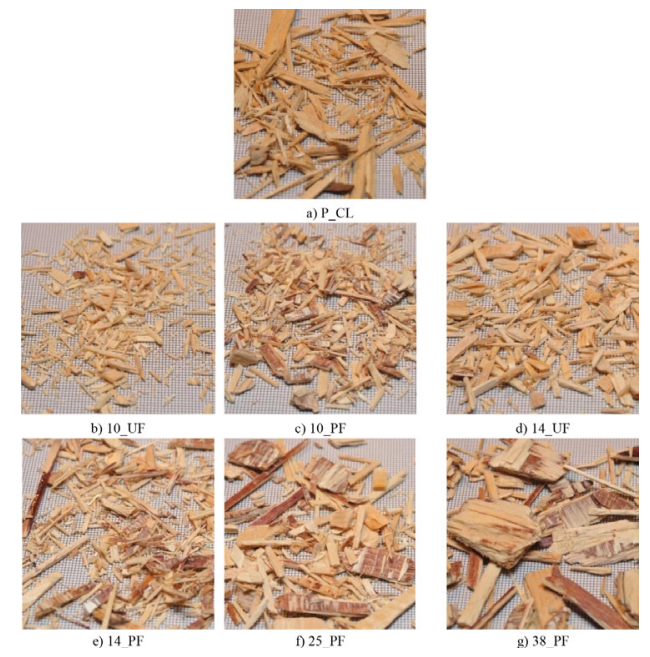

Figure 1: Recovered particles from waste plywood.

In order to accurately analyze the material, each grade was sorted into 9 fractions including dust. Finally, each grade was divided into 4 groups: large particles $(4,00-10,00 \mathrm{~mm}$ sieve $)$, medium particles $(2,00$ and 1,25 $\mathrm{mm}$ sieves), fine particles $(0,63-0,32 \mathrm{~mm}$ sieve) and dust. Fractional composition of the reference industrial particles (P_CL) was as follows: 25,7; 59,1;13,8;1,4\%; respectively, for large, medium, fine particles and dust (Table 1).

Table 1: Fractional composition of the industrial particles (P_CL) and recovered particles from waste plywood.

\begin{tabular}{|c|c|c|c|c|}
\hline \multirow{5}{*}{ Mixture } & \multicolumn{4}{|c|}{ Fractions (\%) } \\
\hline & \multicolumn{4}{|c|}{ Sieve mesh size $(\mathrm{mm})$} \\
\hline & $<0,32$ & $0,32-0,63$ & $1,25-2,00$ & $4,00-10,00$ \\
\hline & \multirow{2}{*}{ dust } & \multicolumn{3}{|c|}{ particles } \\
\hline & & fine & medium & large \\
\hline P_CL & $1,4(0,1)$ & $13,8(1,5)$ & $59,1(4,7)$ & $25,7(2,9)$ \\
\hline 10_UF & $* 2,3(0,2)$ & $* 19,3(1,9)$ & $64,8(5,4)$ & $* 13,6(1,5)$ \\
\hline 10_PF & $* 2,3(0,2)$ & $* 19,3(1,9)$ & $62,7(5,2)$ & $* 15,7(1,5)$ \\
\hline 14_UF & $* 1,7(0,1)$ & $12,5(1,4)$ & $57,9(4,7)$ & $27,9(3,3)$ \\
\hline 14_PF & $* 2,2(0,2)$ & $16,1(1,6)$ & $54,9(4,5)$ & $26,8(2,9)$ \\
\hline 25_PF & $* 0,4(0,1)$ & $* 6,1(0,7)$ & $* 40,6(3,2)$ & $* 52,9(5,7)$ \\
\hline 38_PF & $* 0,5(0,1)$ & $* 4,6(0,5)$ & $* 27,3(2,2)$ & $* 67,6(7,4)$ \\
\hline
\end{tabular}

*Indicates statistically significant values at the significance level 0,05 .

Statistical analysis of the data shown in Table 1 indicates that the type of the binder is not a factor affecting the fractional composition of the recovered particles formed on shredding on 10- and 14-mm mesh screens. A 14-mm mesh screen was found to produce particles of fractional composition close to that of the industrial virgin particles $\left(\mathrm{P} \_\mathrm{CL}\right)$. What is worth noting that $10-$ and $14-\mathrm{mm}$ mesh screens generated higher amounts of dust which is not beneficial as high content of fine particles had been proven to lower physical and mechanical properties of particleboards (Nemli et al. 2007, Sackey et al. 2008). Lower dust content $(0,4-0,5 \%)$ was found in particles shredded on 25- and 38-mm mesh screens, but it was accompanied by substantial amount of large fractions. For $25-$ or $38-\mathrm{mm}$ mesh screens, the large fraction content was $52,9 \%$ and $67,6 \%$ respectively. 
Bulk density of the industrial virgin particles P_CL was $181 \mathrm{~kg} / \mathrm{m}^{3}$ for dry (Figure 2) while recovered particles exhibited significantly higher bulk density. The values determined for the particles produced with 10 and $14-\mathrm{mm}$ mesh screens were, respectively, higher by $65 \%$ and $57 \%$ (at $0 \%$ moisture content). Bulk density of the particles from $25-$ and $38-\mathrm{mm}$ sieves was $48 \%$ and $30 \%$ (at moisture $0 \%$ ) higher, respectively.

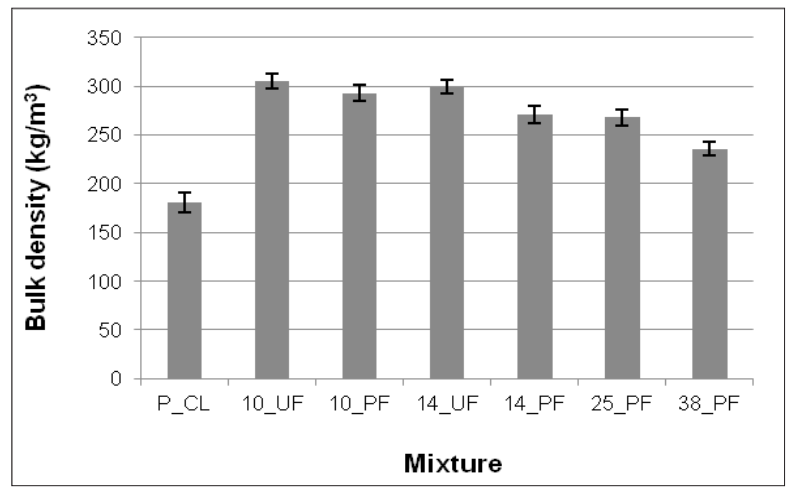

Figure 2: Bulk density of wood particles at moisture $0 \%$.

Higher density of the recovered particles results from the following factors: (I) veneer densification during plywood manufacturing, (II) the content of the cured binders in the material, (III) the shape and dimensions of the particles (fine particles and dust are more tightly packed in a volume unit), (IV) a low moisture content in the waste plywood $(5,8-7,5 \%)$ which eased extra shredding through friction between particles in the shred-chamber. It is known from the literature that higher bulk density affects mat pressing and compaction. Higher density particles form looser mats, so that steam and heat penetration is easier and faster (Bolton et al. 1989, Humphrey and Bolton 1989, Hata et al. 1990, Thoemen and Humphrey 2001). Not only is heat transferred by convection, but by conduction too. It seems that particles recovered from plywood are partially densified, thus their thermal conductivity is increased when compared to the virgin particles. According to Kollmann (1955) a number of factors influence thermal conductivity of wood. These are: species, density, anatomic direction, moisture content and temperature. The difference between the moisture content in the recovered particles $(5,8-7,5 \%)$ and in the virgin particles $(6,7 \%)$ was negligible. Therefore, that factor was not significant in heat transfer to the core of the mats.

Table 2: The length of wood particles.

\begin{tabular}{|c|c|c|c|c|c|c|c|c|c|}
\hline \multirow{3}{*}{ Mixture } & \multirow{3}{*}{ Statistics } & \multicolumn{8}{|c|}{ Sieve mesh size $(\mathrm{mm})$} \\
\hline & & 0,32 & 0,63 & 1,25 & 2,00 & 4,00 & 6,00 & 8,00 & 10,0 \\
\hline & & \multicolumn{8}{|c|}{ Length (mm) } \\
\hline \multirow[t]{2}{*}{ P_CL } & mean & 3,7 & 7,1 & 12,2 & 15,3 & 24,0 & 29,7 & 35,9 & 37,1 \\
\hline & std. dev. & 0,9 & 1,3 & 3,0 & 3,0 & 4,1 & 4,9 & 6,0 & 5,0 \\
\hline \multirow[t]{2}{*}{ 10_UF } & mean & $* 2,2$ & $* 5,0$ & $* 8,9$ & $* 10,0$ & $* 9,4$ & $* 8,9$ & $* 10,5$ & 34,4 \\
\hline & std. dev. & 0,6 & 1,2 & 1,9 & 2,0 & 1,3 & 1,7 & 1,5 & 6,1 \\
\hline \multirow[t]{2}{*}{ 10_PF } & mean & $* 2,3$ & $* 3,9$ & $* 7,3$ & $* 7,1$ & $* 8,3$ & $* 10,8$ & $* 10,2$ & 36,3 \\
\hline & std. dev. & 0,6 & 0,7 & 1,5 & 1,6 & 1,9 & 2,7 & 1,6 & 5,4 \\
\hline \multirow[t]{2}{*}{ 14_UF } & mean & $* 2,5$ & $* 5,7$ & $* 8,9$ & $* 13,1$ & $* 12,3$ & $* 13,0$ & $* 14,1$ & $* 41,9$ \\
\hline & std. dev. & 0,4 & 1,0 & 1,5 & 3,2 & 2,4 & 3,0 & 3,3 & 7,8 \\
\hline \multirow[t]{2}{*}{ 14_PF } & mean & $* 2,9$ & $* 5,0$ & $* 9,4$ & $* 10,4$ & $* 11,2$ & $* 12,2$ & $* 13,8$ & 37,7 \\
\hline & std. dev. & 0,6 & 1,2 & 1,4 & 2,5 & 2,4 & 2,8 & 3,1 & 5,0 \\
\hline \multirow[t]{2}{*}{ 25_PF } & mean & $* 2,3$ & $* 5,5$ & 13,7 & 15,4 & $* 15,7$ & $* 18,8$ & 35,8 & 38,1 \\
\hline & std. dev. & 0,4 & 1,1 & 2,8 & 2,3 & 3,2 & 3,4 & 6,5 & 7,4 \\
\hline \multirow[t]{2}{*}{ 38_PF } & mean & $* 2,2$ & 6,6 & $* 9,3$ & 15,8 & $* 20,0$ & $* 23,8$ & 32,9 & 39,4 \\
\hline & std. dev. & 0,5 & 1,2 & 1,5 & 2,2 & 2,8 & 4,5 & 5,4 & 5,7 \\
\hline
\end{tabular}

* Indicates statistically significant values at the significance level 0,05.

The dimensional analysis revealed that the recovered particles were shorter than the industrial P_CL particles of the respective fraction (Table 2). The particles stopped on the 1,25-mm screen (25_PF), 2,00-mm screen (25_PF and 38_PF) and 10,00-mm screen (14_UF, 14_PF, 25_PF and 38_PF) were longer when compared to the $\overline{\mathrm{P}} \mathrm{CL}$ reference. The particles shredded with a $25-\mathrm{mm}$ mesh screen exhibited properties closest to those found for the industrial P_CL. 
Table 3: The width of wood particles.

\begin{tabular}{|c|c|c|c|c|c|c|c|c|c|}
\hline \multirow{3}{*}{ Mixture } & \multirow{3}{*}{ Statistics } & \multicolumn{8}{|c|}{ Sieve mesh size $(\mathrm{mm})$} \\
\hline & & 0,32 & 0,63 & 1,25 & 2,00 & 4,00 & 6,00 & 8,00 & 10,0 \\
\hline & & \multicolumn{8}{|c|}{ Width (mm) } \\
\hline \multirow[t]{2}{*}{ P_CL } & mean & 0,4 & 0,8 & 1,2 & 1,9 & 3,5 & 4,5 & 5,5 & 5,9 \\
\hline & std. dev. & 0,1 & 0,1 & 0,2 & 0,3 & 0,8 & 1,0 & 1,2 & 1,3 \\
\hline \multirow[t]{2}{*}{ 10_UF } & mean & 0,4 & 0,8 & 1,2 & $* 2,2$ & $* 4,2$ & $* 6,2$ & $* 8,7$ & $* 3,7$ \\
\hline & std. dev. & 0,1 & 0,1 & 0,1 & 0,4 & 0,5 & 0,7 & 1,1 & 0,9 \\
\hline \multirow[t]{2}{*}{ 10_PF } & mean & 0,4 & $*_{0,6}$ & $* 1,0$ & $* 2,5$ & $* 4,8$ & $* 6,6$ & $* 8,7$ & $* 4,0$ \\
\hline & std. dev. & 0,1 & 0,1 & 0,2 & 0,6 & 0,5 & 0,7 & 0,7 & 0,9 \\
\hline \multirow[t]{2}{*}{ 14_UF } & mean & 0,4 & $* 0,9$ & $* 1,7$ & $* 2,8$ & $* 4,4$ & $* 6,2$ & $* 8,2$ & 5,4 \\
\hline & std. dev. & 0,1 & 0,1 & 0,3 & 0,3 & 0,8 & 0,8 & 1,6 & 1,1 \\
\hline \multirow[t]{2}{*}{ 14_PF } & mean & 0,4 & $* 0,7$ & $* 1,4$ & 2,1 & $* 4,7$ & $* 5,7$ & $* 8,2$ & $* 4,7$ \\
\hline & std. dev. & 0,1 & 0,1 & 0,2 & 0,3 & 0,6 & 1,1 & 0,8 & 0,6 \\
\hline \multirow[t]{2}{*}{ 25_PF } & mean & 0,4 & $* 1,0$ & $*^{*} 1,4$ & $* 3,1$ & $* 4,1$ & $* 6,3$ & $* 7,8$ & $* 12,9$ \\
\hline & std. dev. & 0,1 & 0,1 & 0,2 & 0,5 & 0,4 & 1,0 & 0,9 & 1,9 \\
\hline \multirow[t]{2}{*}{ 38_PF } & mean & 0,5 & $* 0,9$ & $* 1,4$ & $* 2,9$ & 3,7 & $* 5,2$ & $* 7,8$ & $* 14,3$ \\
\hline & std. dev. & 0,1 & 0,2 & 0,2 & 0,3 & 0.6 & 0,6 & 1,2 & 2,2 \\
\hline
\end{tabular}

*Indicates statistically significant values at the significance level 0,05.

The values in Table 3 show that the average width for the most fractions of the recovered particles was greater than that of the P_CL. However, fractions stopped on 0,63-mm (10_PF and 14_PF), 1,25-mm (10_PF), 10,00-mm (10_UF, $10 \_\overline{P F}, 14$ PF) screens were narrower when compare $\overline{\text { d }}$ to the reference P_CL. The observation can be explained by the shredding mode where plywood was cut simultaneously along and across the fibers. The dimensions of the particles shredded with a $14-\mathrm{mm}$ screen were closest to those for the industrial particles.

Table 4: The thickness of wood particles.

\begin{tabular}{|c|c|c|c|c|c|c|c|c|c|}
\hline \multirow{3}{*}{ Mixture } & \multirow{3}{*}{ Statistics } & \multicolumn{8}{|c|}{ Sieve mesh size $(\mathrm{mm})$} \\
\hline & & 0,32 & 0,63 & 1,25 & 2,00 & 4,00 & 6,00 & 8,00 & 10,0 \\
\hline & & \multicolumn{8}{|c|}{ Thickness (mm) } \\
\hline \multirow[t]{2}{*}{ P_CL } & mean & 0,12 & 0,49 & 0,81 & 1,09 & 1,31 & 1,34 & 1,48 & 1,65 \\
\hline & std. dev. & 0,03 & 0,12 & 0,20 & 0,16 & 0,27 & 0,32 & 0,28 & 0,42 \\
\hline \multirow[t]{2}{*}{ 10_UF } & mean & $* 0,08$ & 0,46 & 0,89 & 1,10 & $* 1,64$ & $* 2,05$ & $* 2,26$ & 1,48 \\
\hline & std. dev. & 0,02 & 0,11 & 0,20 & 0,25 & 0,24 & 0,29 & 0,38 & 0,14 \\
\hline \multirow[t]{2}{*}{ 10_PF } & mean & $* 0,09$ & $* 0,25$ & $* 0,57$ & 1,11 & $* 1,67$ & $* 1,92$ & $* 2,44$ & 1,54 \\
\hline & std. dev. & 0,02 & 0,05 & 0,10 & 0,27 & 0,33 & 0,29 & 0,52 & 0,23 \\
\hline \multirow[t]{2}{*}{ 14_UF } & mean & 0,14 & 0,56 & $* 1,03$ & $* 1,45$ & $* 1,90$ & $* 2,07$ & $* 2,49$ & 1,61 \\
\hline & std. dev. & 0,03 & 0,10 & 0,19 & 0,29 & 0,43 & 0,35 & 0,53 & 0,23 \\
\hline \multirow[t]{2}{*}{ 14_PF } & mean & $* 0,15$ & $* 0,37$ & 0,93 & 1,12 & $* 1,58$ & $* 1,82$ & $* 2,25$ & 1,64 \\
\hline & std. dev. & 0,04 & 0,08 & 0,22 & 0,26 & 0,22 & 0,38 & 0,41 & 0,25 \\
\hline \multirow[t]{2}{*}{ 25_PF } & mean & 0,13 & 0,51 & 0,86 & $* 1,42$ & $* 1,74$ & $* 1,86$ & $* 2,25$ & $* 3,12$ \\
\hline & std. dev. & 0,03 & 0,12 & 0,18 & 0,15 & 0,29 & 0,34 & 0,42 & 0,61 \\
\hline \multirow[t]{2}{*}{ 38_PF } & mean & $* 0,10$ & 0,48 & 0,84 & $* 1,41$ & $* 1,59$ & $* 1,85$ & $* 2,31$ & $* 3,11$ \\
\hline & std. dev. & 0,02 & 0,11 & 0,13 & 0,19 & 0,18 & 0,22 & 0,33 & 0,53 \\
\hline
\end{tabular}

*Indicates statistically significant values at the significance level 0,05.

The obtained results indicate that the fractions of the recovered particles stopped on 2,00-mm and finer sieves exhibited thickness comparable to that of the P_CL, while the greater fractions stopped on 4,00-; 6,00and $8,00-\mathrm{mm}$ sieve were of higher thickness and the differences were statistically significant (Table 4).

The reference P_CL particle thickness values distribution was narrow. The peak thickness was $2,50 \mathrm{~mm}$ (Figure 3a). The average thickness for the mixture computed from the weighted arithmetic mean values (indicated as a black line) was $1,00 \mathrm{~mm}$. In the $\mathrm{P} C \mathrm{CL}$, the shares of the fractions: $<0,50 \mathrm{~mm}, 0,50-1,75 \mathrm{~mm}$ and $>1,75 \mathrm{~mm}$ thick were, respectively, $20 \%, 72 \%$ and $8 \%$. The thickness distribution found for the recovered particles (Figure 3b, Figure 3c, Figure 3d, Figure 3e, Figure $3 \mathrm{f}$ and Figure 3g) was different. Thickness varied in a wide range with the maximum value at $4,00 \mathrm{~mm}$. The content of $0,50-1,75-\mathrm{mm}$ fractions was lower by $25 \%$ and $38 \%$, respectively, for the 10_UF and 10_PF particles. While the content of $0,50-1,75-\mathrm{mm}$ fractions was lower by $33 \%$ and $29 \%$, respectively, for the 14 _UF and 14_PF particles.

In general share of thicker particles in the recovered mixtures when compared to the industrial particle significantly increased. The range of thickness of the recovered particles was wider than that for the P_CL. The phenomenon confirms our postulate on the veneer reinforcement due to the binder penetration into the material. The thickness of particles is crucial both for the manufacturing process and for resultant properties of the particleboards. Thickness, unlike the other dimensions, cannot be corrected during the process (e.g. by secondary shredding). Thick particles are less prone to deformation during pressing, so that the particles fitting is poorer and lower contact area is developed (Badejo 1988, Suchsland and Woodson 1991). Those phenomena affect the modulus of rupture and internal bond of a board (Hutschneker 1975, Niemz 1993). That is why it is necessary to produce particles of the thickness as close to that projected for the process as possible. 


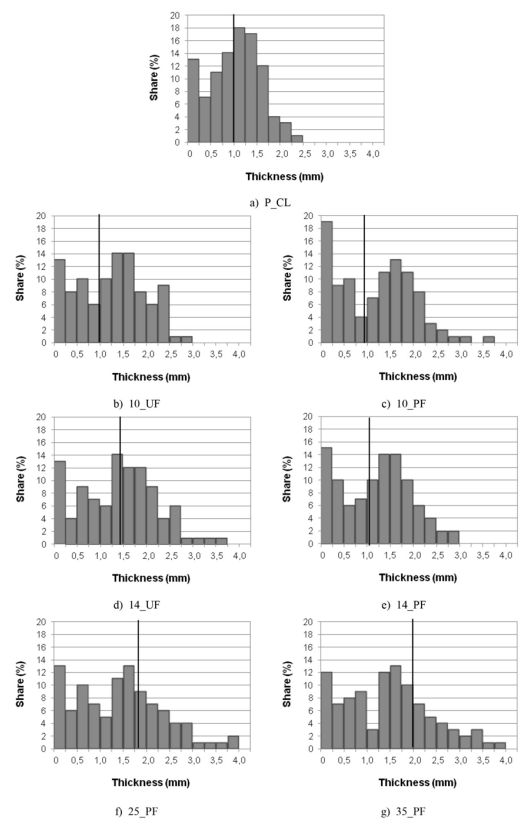

Figure 3: Particle thickness distribution around the mean value (black line).

Table 5: Dimensions and surface area of the average particle.

\begin{tabular}{|l|c|c|c|c|}
\hline \multirow{2}{*}{ Mixture } & Length & Width & Thickness & $\begin{array}{c}\text { Surface } \\
\text { area }\end{array}$ \\
\cline { 2 - 5 } & \multicolumn{4}{|c|}{$(\mathrm{mm})$} \\
\hline P_CL & 16,6 & 2,2 & 1,00 & $\left(\mathrm{~m}^{2} / \mathrm{kg}\right)$ \\
\hline 10_UF & 8,6 & 2,0 & 0,99 & 6,6 \\
\hline 10_PF & 6,8 & 2,2 & 0,91 & 5,1 \\
\hline 14_UF & 11,5 & 3,1 & 1,39 & 3,5 \\
\hline 14_PF & 10,0 & 2,6 & 1,12 & 4,3 \\
\hline 25_PF & 19,9 & 5,1 & 1,71 & 2,6 \\
\hline 38_PF & 25,3 & 7,0 & 2,00 & 2,1 \\
\hline
\end{tabular}

Average dimensions and surface area of particles are shown in Table 5. It is clear that the particles produced in the shredder equipped with a 14-mm mesh screen (particles of fractional composition close to that of the P_CL) were $35 \%$ shorter, $30 \%$ wider and $26 \%$ thicker than the reference industrial particles P_CL. As far as the surface area is concerned, the highest value was obtained for the particles shredded on a 10-mm mesh screen. Particle surface area is a parameter that influences the properties of the resultant particleboards. The lower surface area, the lower bondline area is developed, so that the mechanical performance of the boards can be strongly affected (Moslemi 1974, Nemli et al. 2007, Yemele et al. 2008).

\section{CONCLUSIONS}

It has been demonstrated that binder type (UF or PF) in plywood had no significant effect on the dimensional characteristics of the particles produced. The screen mesh size used in a shredder had a dominating effect on the fractional composition, bulk density and dimensions of the recovered particles. Unlike for the particles obtained from 25-and 38-mm mesh screens, the content of dust in the particles from 10- and 14-mm screens was lower than that in the virgin industrial particles. It was shown that the particles obtained with a 14-mm mesh screen exhibited the properties closest to those determined for the industrial virgin particles. An average recovered particle was 35\% shorter, 30\% wider and 26\% thicker than an average reference one. The presented results showed that it was possible to use waste plywood as a resource of recovered particles exhibiting the properties comparable to those of the industrial particles. Thus, it is postulated that waste plywood can be recycled to particles for particleboard manufacturing. 


\section{REFERENCES}

Azambuja, R. da R.; de Castro, V.G.; Trianoski, R.; Iwakiri, S. 2018. Recycling wood waste from construction and demolition to produce particleboards. Maderas-Cienc Tecnol 20 (4): 681-690. https://doi. org/10.4067/S0718-221X2018005041401.

Badejo, S.O.O. 1988. Effect of flake geometry on properties of cement-bonded particleboard from mixed tropical hardwoods. Wood Sci Technol 22 (4): 357-369. https://doi.org/10.1007/BF00353325.

Bardak, S.; Nemli, G.; Bardak, T. 2019. The quality comparison of particleboards produced from heartwood and sapwood of European larch. Maderas-Cienc Tecnol 21 (4): 511-520. https://doi.org/10.4067/S0718$221 X 2019005000407$.

Bolton, A.J.; Humphrey, P.E.; Kavvouras, P.K. 1989. The hot pressing of dry - formed wood - based composites. Part III. Predicted vapour pressure and temperature variation with time, compared with experimental data for laboratory boards. Holzforschung 43 (4): 265-274. https://doi.org/10.1515/hfsg. 1989.43.4.265.

Czarnecki, R.; Dziurka, D.; Lęcka, J. 2003. The use of recycled boards as the substitute for particles in the centre layer of particleboards. Electronic Journal of Polish Agricultural Universities, Wood Technology 6(2), \#01. http://www.ejpau.media.pl/volume6/issue2/wood/art-01.html.

Demirkir, C.; Çolakoğlu, G. 2007. Formaldehyde emission from particleboards manufactured with waste materials from plywood industry. Holz Roh Werkst 65 (6): 483-484. https://doi.org/10.1007/s00107-007-0202-8.

European Parliament, Council of the European Union. 2009. 2009/28/EC of the European Parliament and of the Council of 23 April 2009 on the promotion of the use of energy from renewable sources and amending and subsequently repealing Directives 2001/77/EC and 2003/30/EC. Official Journal of the European Union L 140.pp. 16-62. Document 32009L0028. https://eur-lex.europa.eu/legal-content/EN/ ALL/?uri=CELEX\%3A32009L0028.

EN. 1993. Wood-based panels - Determination of density. EN 323. 1993. European Committee for Standardization: Brussels, Belgium.

Gamage, N.; Setunge, S.; Jollands, M.; Hague, J. 2009. Properties of hardwood saw mill residue - based particleboards as affected by processing parameters. Ind Crops Prod 29 (1): 248-254. https://doi.org/10.1016/j. indcrop.2008.05.012.

Graser, M. 1962. Temperaturvelauf in industriell gefertigten Spanplatten während des Preßvorgangs, festgestellt durch Meßsonden (Thermocouple-monitored temperature distribution in particleboards manufactured under industrial pressing conditions). Holz - Zentralblatt 137(4): 6-8.

Hata, T.; Kawai, S.; Sasaki, H. 1990. Production of particleboard with steam-injection. Part 2: Computer simulation of temperature behavior in particle mat during hotpressing and steam-injection pressing. Wood Sci Technol 24 (1): 65-78. https://doi.org/10.1007/BF00225307.

Hernández, R.E.; Passarini, L.; Koubaa, A. 2014. Effects of temperature and moisture content on selected wood mechanical properties involved in the chipping process. Wood Sci Technol 48 (6): 1281-1301. https://doi.org/10.1007/s00226-014-0673-9.

Hillring, B.; Canals, G.; Olsson, O. 2007. Market for recovered wood in Europe - an overview. In: Gallis Ch. (ed.) Management of Recovered Wood, University Studio Press: Thessaloniki, Greece, pp. 201-213.

Humphrey, P.E.; Bolton, A.J. 1989. The hot pressing of dry - formed wood - based composites. Part II. A simulation model for heat and moisture transfer, and typical results. Holzforschung 43 (3): 199-206. https:// doi.org/10.1515/hfsg.1989.43.3.199.

Hutschneker, K. 1975. Neuere Entwicklungen auf dem Spanplattengebiet. Holz Roh Werkst 33 (10): 357-364. https://doi.org/10.1007/BF02611201.

ISO. 2014. Physical and mechanical properties of wood - Test methods for small clear wood specimens - Part 2: Determination of density for physical and mechanical tests. ISO 13061-2. 2014. International Orga- 
nization for Standardization: Geneva, Switzerland.

Kollmann, F. 1955. Technologie des Holzes und der Holzwerkstoffe. Springer - Verlag: Berlin, Germany.

Kurowska, A. 2015. Waste wood under Polish and European Union law. Sylwan 159 (5): 355-360.

Kurowska, A. 2016. Waste wood supply structure in Poland. Sylwan 160 (3): 187-196.

Lykidis, C.H.; Grigoriou, A. 2008. Hydrothermal recycling of waste and performance of the recycled wooden particleboards. Waste Manage 28 (1): 57-63. https://doi.org/10.1016/j.wasman.2006.11.016.

Mantau, U. 2010. Wood Resource Balance results - is there enough wood for Europe? In: Mantau U. et al. (ed.) EUwood - Real potential for changes in growth and use of EU forests. Final report, Hamburg, Germany, pp 19-34.

Merl, A.D.; Humar, M.; Okstad, T.; Picardo, V.; Ribeiro, A.; Steierer, F. 2007. Amounts of recovered wood in COST E31 countries and Europe. In: Gallis Ch. (ed.) Management of Recovered Wood. University Studio Press: Thessaloniki, Greece, pp 79-116.

Meyer B. 1969. Zum Problem der Bestimmung der spezifischen aeusseren Oberflaeche von Holz und Holzpartikeln. Holztechnologie.

Moslemi, A.A. 1974. Particleboard. Volume 1: Materials. Southern Illinois University Press, Carbondale, USA.

Mundy, J.S.; Bonfield, P.W. 1998. Predicting the short-term properties of chipboard using composite theory. Wood Sci Technol 32 (3): 237-245. https://doi.org/10.1007/BF00704846.

Nazerian, M.; Ghalehno, M.D.; Shojaiishad, M.; Sharifpoor, H.; Taftiyan, M.H. 2011. Properties of Three - layer Particleboard Made from Wood of Athel (Tamarix aphylla) and Pruning Particles of Almond (Amygdalus communis) and Pistachio (Pistacia vera). J Basic Appl Sci Res 1 (8): 837-843.

Nemli, G.; Aydin, I.; Zekoviç, E. 2007. Evaluation of some of the properties of particleboard as function of manufacturing parameters. Mater Des 28 (4): 1169-1176. https://doi.org/10.1016/j.matdes.2006.01.015.

Niemz, P. 1993. Physik des Holzes und der Holzwerkstoffe. ETH Zurich Research Collection: Leinfelden - Echterdingen, Germany. https://doi.org/10.3929/ethz-a-010635628

Sackey, E.K.; Semple, K.E.; OH, S.-W.; Smith, G.D. 2008. Improving Core Bond Strength of Particleboard Through Particle Size Redistribution. Wood Fiber Sci 40 (2): 214-224.

Suchsland, O.; Woodson, G.E. 1991. Fibreboards manufacturing practices in United States. Department of Agriculture, Forest Service, USA.

Thoemen, H.; Humphrey, P.E. 2001. Hot pressing of wood - based composites: selected aspects of the physics investigated by means of simulation. Proceedings of the 5th European Panel Products Symposium, October 10-12, 2001, Llandudno Wales U.K., pp 38-49.

Van Benthem, M.; Leek, N.; Mantau, U.; Weimar, H. 2007. Markets for recovered wood in Europe: case studies for the Netherlands and Germany based on the bioxchange project. Detection methods in practical application. In: Gallis Ch. (ed.) Management of Recovered Wood, University Studio Press: Thessaloniki, Greece, pp 215-228.

Yemele, M.C.N.; Blanchet, P.; Cloutier, A.; Koubaa, A. 2008. Effects of bark content and particle geometry on the physical and mechanical properties of particleboard made from black spruce and trembling aspen bark. Forest Prod J 58 (11): 48-56.

Zbořil, J.; Pesci, P. 2011. Opinion of the European Economic and Social Committee on 'Opportunities and challenges for a more competitive European woodworking and furniture sector' (own-initiative opinion). Official Journal of the European Union C 24. Document 52011IE1598. pp 18-23. https://eur-lex.europa.eu/ legal-content/EN/TXT/?uri=CELEX\%3A52011IE1598. 